\title{
Erratum
}

\section{DNA and morphological markers for a Russian wheat aphid resistance gene}

\author{
A. Arzani ${ }^{1,2, *}$, J.H. Peng ${ }^{1} \&$ N.L.V. Lapitan ${ }^{1}$ \\ ${ }^{1}$ Department of Soil and Crop Sciences, Colorado State University, Fort Collins, CO 80523, U.S.A.; \\ ${ }^{2}$ Agronomy and Plant Breeding Department, College of Agriculture, Isfahan University of Technology, \\ Isfahan (*author for correspondence: e-mail: a_arzani@cc.iut.ac.ir)
}

Euphytica, Vol. 139, No. 2, pp. 167-172 (2004)

In this alticle there has been an unfortunate misrepresentation of a figure. It concerns an incorrect version of Figure 1 on page 170. The correct reproduction of this figure is published below:

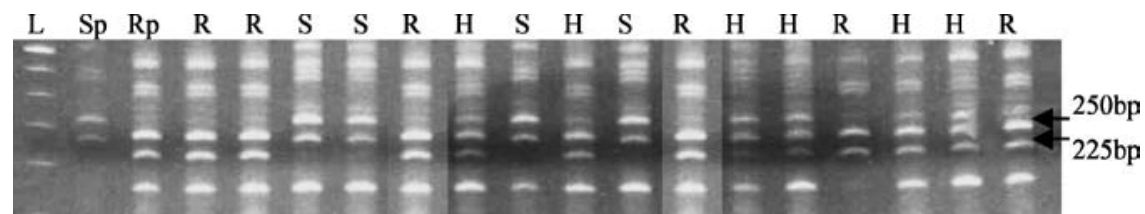

Figure 1. DNA bands amplified from leaves of $\mathrm{F}_{2}$-derived $\mathrm{F}_{3}$ families of synthetic hexaploid-11 (susceptible parent, $\mathrm{Sp}$ ) $\times$ 'Halt' (RWA resistant parent containing $\mathrm{Dn} 4, \mathrm{Rp}$ ), using microsatellite $\mathrm{Xgwm} 337$ marker and electrophoresed in a $7 \%$ polyacrylamide gel. $L=50$ bp ladder, $\mathrm{R}$ : homozygous resistant, $\mathrm{S}$ : susceptible, $\mathrm{H}$ : heterozygous $\mathrm{F}_{3}$ families ( $\mathrm{F}_{2}$ plants); about $110 \mathrm{~F}_{2: 3}$ families were evaluated. 